\title{
Insulin Receptor Down-regulation Is Linked to an Insulin-induced Postreceptor Defect in the Glucose Transport System in Rat Adipocytes
}

\author{
W. Timothy Garvey, J. M. Olefsky, and Stephen Marshall \\ Division of Endocrinology and Metabolism, Department of Medicine, University of California, \\ San Diego School of Medicine, La Jolla, California 92093
}

\begin{abstract}
We have examined the relationship between insulin-induced receptor downregulation and the induction of a postreceptor defect in the insulin-stimulated glucose transport system in rat adipocytes, and found that downregulation was linked to the expression of the postreceptor defect. When recycling of insulin receptors was inhibited by $20 \mathrm{mM}$ Tris, insulin pretreatment $\left(100 \mathrm{ng} / \mathrm{ml}\right.$ ) for $4 \mathrm{~h}$ at $37^{\circ} \mathrm{C}$ induced both net loss $(65 \%)$ of cell-surface receptors and a $63 \%$ decrease in maximal insulin responsiveness. In contrast, when cells were treated with insulin alone for $4 \mathrm{~h}$ at $37^{\circ} \mathrm{C}$ so that receptors could recycle, or treated at $16^{\circ} \mathrm{C}$ with Tris plus insulin to inhibit receptor internalization, neither receptor downregulation nor a postreceptor defect was observed. Induction of the postreceptor defect was specific for insulin under conditions when downregulation would occur, since treatment of cells with Tris and the insulin mimicker spermine did not result in receptor loss or the postreceptor defect. Other experiments revealed that receptor downregulation occurred first without loss of insulin responsiveness, but, once the postreceptor defect appeared, its severity was correlated to the degree of further receptor loss, as a function of insulin dose and exposure time. Tris (20 $\mathrm{mM}$ ) alone acutely decreased maximally stimulated glucose transport rates slightly (22\%), but this effect was rapidly reversible after Tris removal and could not have been directly responsible for the lasting and profound postreceptor defect seen after pretreatment with insulin plus Tris. Taken together, these data suggest that insulin-induced receptor loss is linked to the induction of the postreceptor defect.
\end{abstract}

The postreceptor defect was due to an inability to maximally increase the maximum velocity of glucose transport. Furthermore, the expression of the postreceptor defect depended upon the extent to which the glucose transport system was allowed to deactivate; maintaining the glucose transport system in an activated state prevented its expression. Thus, the mechanism could involve rapid inactivation or sequestration of glucose transporters during deactivation such that they become refractory to the subsequent stimulatory effects of insulin.

In conclusion, $(a)$ insulin does not acutely induce a postreceptor defect in the glucose transport system of adipocytes without loss of cell-surface insulin receptors; $(b)$ the defect in stimulated glucose transport has been induced distal to the insulin receptor via a mechanism linked to receptor loss; and (c) the postreceptor lesion is due to decreased numbers or

Address correspondence to Dr. Garvey.

Received for publication 15 November 1984.

J. Clin. Invest.

(c) The American Society for Clinical Investigation, Inc. 0021-9738/85/07/0022/09 \$1.00

Volume 76, July 1985, 22-30 intrinsic activity of glucose transporters on the cell-surface in the presence of a maximally effective insulin concentration. These data suggest that insulin receptor downregulation and postreceptor defects in insulin action, which frequently co-exist both in vivo and in vitro, may be linked mechanistically.

\section{Introduction}

In earlier studies (1) we showed that treatment of isolated adipocytes with a high insulin concentration leads to a rapid decrease in the number of cell-surface receptors $(50 \%$ by $2 \mathrm{~h}$, $70 \%$ by $4 \mathrm{~h}$ ), when Tris [tris(hydroxymethyl)aminomethane] is present in the incubation buffer. We also evaluated the relationship between the decrease in insulin binding and the subsequent biologic effect of insulin to promote glucose transport (2). Early insulin receptor downregulation was accompanied by a proportional rightward shift in the insulin doseresponse curve, and with more prolonged insulin exposure (4 h) there was a further shift accompanied by a marked decrease in the ability of insulin to maximally stimulate glucose transport. This latter abnormality was attributed to a postreceptor defect in the glucose transport system (i.e., the cellular components that provide for the facilitated entry of glucose). Therefore, insulin treatment of adipocytes decreased both sensitivity and maximal responsiveness through defects at the receptor and postreceptor level, respectively. However, it remained unclear whether insulin-induced receptor loss was necessary for the induction of the postreceptor defect or whether the postreceptor defect was the result of the biologic action of insulin per se.

Since these studies, we found that during acute insulin treatment $(2-4 \mathrm{~h})$ receptors are normally endocytosed and then efficiently recycled so that a net loss of cell-surface receptors does not occur (3). Furthermore, Tris, a constituent of the original in vitro adipocyte incubation buffer, was found to inhibit endocytosed receptors from recycling back to the plasma membrane $(3,4)$. Since the number of surface receptors represents an equilibrium between the rates of receptor internalization and recycling, inhibition of recycling allowed internalization to predominate and resulted in the rapid depletion of cell surface receptors. When adipocytes are maintained in primary culture in the absence of Tris, insulin incubation does not result in net loss of surface receptors for $\sim 12 \mathrm{~h} \mathrm{(5).}$

These more recent findings have given us the opportunity to examine whether the insulin-induced postreceptor defect in glucose transport is due to the biologic action of insulin per se, or whether receptor downregulation is necessary for its development. Specifically, we could stimulate cells with insulin under recycling conditions where no net loss of surface receptors occurs, or under conditions where recycling is inhibited by Tris, and then assess the subsequent effect on insulin-stimulated 
glucose transport. The relationship between receptor loss and insulin action is interesting, since co-existing receptor and postreceptor defects have been described in vitro $(2,6-12)$ for various cell types, and also in patients with type II diabetes mellitus $(13,14)$. Similarly, obesity is a hyperinsulinemic insulin-resistant state in which many, but not all (15), studies demonstrate receptor defects associated with postreceptor defects both in vitro (16) and in vivo (17). However, the relationship between insulin receptor downregulation and the development of postreceptor defects in insulin action is unknown. In the current study we demonstrate in rat adipocytes that insulin induces a postreceptor defect in glucose transport, via a mechanism linked to receptor downregulation, which involves an abnormality in plasma membrane glucose transporters.

\section{Methods}

Materials. Porcine monocomponent insulin was generously supplied by Dr. Ronald Chance and A-14-mono- ${ }^{125}$ I-insulin by Dr. Bruce Frank both of Eli Lilly and Co. (Indianapolis, IN). ${ }^{125} \mathrm{I}-\mathrm{Na}, \mathrm{L}-1-\left[{ }^{3} \mathrm{H}\right]$ glucose, and $\mathrm{D}-3-\mathrm{O}$-methyl[ $\left.\mathrm{U}-{ }^{14} \mathrm{C}\right]$ glucose were purchased from New England Nuclear (Boston, MA); 2-deoxy-D- $\left[{ }^{3} \mathrm{H}\right]$ glucose from Amersham Corp. (Arlington Heights, IL); bovine serum albumin (fraction V) from Armour Pharmaceutical Co. (Chicago, IL); collagenase from Worthington Biochemical Corp. (Freehold, NJ); tris(hydroxymethyl)aminomethane (Tris), 4-(2-hydroxyethyl)-1-piperazineethanesulfonic acid (Hepes), D-glucose, L-glucose, D-2-deoxyglucose, and D-3-O-methylglucose from Sigma Chemical Co. (St. Louis, MO); phloretin from Spectrum Chemical Corp. (Gardena, CA), silicone oils from Union Carbide Corp. (Danbury, CT); Dulbecco's modified Eagle's medium $(D M E)^{1}$ from Gibco Laboratories Inc. (Grand Island, NY); and spermine tetrahydrochloride from ICN Nutritional Biochemicals (Cleveland, $\mathrm{OH})$.

Preparation of isolated adipocytes. Male Sprague-Dawley rats, 180 $275 \mathrm{~g}$, were killed by cervical dislocation, and the epididymal fat pads were removed. Isolated adipocytes were obtained by use of a method modified from Rodbell (18), as previously described (5), except that cells were washed in DME containing $20 \mathrm{mM}$ Hepes and $1 \%$ bovine serum albumin. Adipocyte counts were performed according to a modification of method III of Hirsch and Gallian (19), as previously described (5).

Insulin pretreatment and washing procedures. $10-20 \mathrm{ml}$ of adipocytes $\left(2 \times 10^{5}\right.$ cells $\left./ \mathrm{ml}\right)$ were suspended in DME, $\mathrm{pH} 7.5$, containing 20 $\mathrm{mM}$ Hepes and $1 \%$ bovine serum albumin, and incubated in $50-\mathrm{ml}$ polypropylene tubes with and without $20 \mathrm{mM}$ Tris, in the absence and presence of $100 \mathrm{ng} / \mathrm{ml}$ insulin. The D-glucose concentration in all buffers containing DME was $5 \mathrm{mM}$. Cells were gently agitated in a shaking water bath from 0 to $6 \mathrm{~h}$ at $37^{\circ} \mathrm{C}$. After the incubation cells were washed three times in equal volumes of glucose-free buffer, $\mathrm{pH}$ 7.0 , consisting of $20 \mathrm{mM}$ Hepes, $120 \mathrm{mM} \mathrm{NaCl}, 1.2 \mathrm{mM} \mathrm{MgSO}_{4}, 2.0$ $\mathrm{mM} \mathrm{CaCl}, 2.5 \mathrm{mM} \mathrm{KCl}, 1.0 \mathrm{mM} \mathrm{NaH} \mathrm{PO}_{4}, 1.0 \mathrm{mM}$ sodium pyruvate, and $1 \%$ bovine serum albumin. The cells were then incubated in this buffer for $1 \mathrm{~h}$ more at $37^{\circ} \mathrm{C}$ to dissociate any remaining receptor-bound insulin. Cells were then resuspended in an equal volume of the glucose-free buffer at $\mathrm{pH}$ 7.4. These washing procedures effectively removed all extracellular and receptor-bound insulin, and the additional hour at $37^{\circ} \mathrm{C}$ allowed the glucose transport system to deactivate to basal levels. In all cases, control cells underwent similar washing, dissociation, and centrifugation procedures as insulin- and/ or Tris-treated cells, and glucose uptake measurements were concomitant for both groups of cells.

1. Abbreviation used in this paper: DME, Dulbecco's modified Eagle's medium.
2-Deoxyglucose transport. After these preincubation and washing procedures were done, control and pretreated adipocytes $\left(2 \times 10^{5}\right.$ cells/ $\mathrm{ml}$ ) were suspended in the glucose-free buffer at pH 7.4 and incubated ( $1 \mathrm{ml} \mathrm{vol}$ ) in the absence and presence of various insulin concentrations in a shaking water bath at $37^{\circ} \mathrm{C}$ for $1 \mathrm{~h}$. Glucose uptake was then measured by adding $50 \mu \mathrm{l} 2$-deoxyglucose that contained $0.2 \mu \mathrm{Ci} 2$ deoxy $\left[1-{ }^{3} \mathrm{H}\right]$ glucose (final concentration $0.1 \mathrm{mM}$ ), and the reaction was terminated after $3 \mathrm{~min}$ by separating cells (300- $\mu$ l aliquots) from buffer by centrifugation through oil, as previously described (2). In each experiment, 2-deoxyglucose uptake at each point represents the mean of triplicate determinations, and each experiment is representative of at least three similar experiments unless otherwise indicated.

3-O-Methylglucose transport. 3-O-methylglucose transport was assayed by a modification of the method of Whitesell and Gliemann (20), as previously described by Foley et al. (21). To assess the saturation kinetics of 3-O-methylglucose transport (Fig. 8), both radiolabeled and unlabeled substrate were included, and hexose concentrations ranged from 0.1 to $9.1 \mathrm{mM}$. To ensure that only initial rates of 3- $O$-methylglucose uptake were measured, reaction times were varied from 12 to $60 \mathrm{~s}$ under basal conditions, but from 1 to $4 \mathrm{~s}$ with maximal insulin stimulation. In all cases, the intracellular methylglucose space upon termination of the reaction was $\leq 30 \%$ of that at equilibrium. The coefficient of variation for $1 \mathrm{~s}$ measurements was $<8 \%$.

Measurement of cell-surface receptors. Cells were washed to remove extracellular and receptor-bound insulin as described above, except that the cells were resuspended in an equal volume of DME at $\mathrm{pH}$ 7.8, rather than in glucose-free buffer at $\mathrm{pH} 7.4$. 1-ml aliquots of adipocytes $\left(2 \times 10^{5}\right.$ cells $\left./ \mathrm{ml}\right)$ were then incubated in a shaking water bath at $16^{\circ} \mathrm{C}$ with $0.2 \mathrm{ng}{ }^{125} \mathrm{I}$-insulin in the absence and presence of $50 \mu \mathrm{g}$ of unlabeled insulin. Note that measurements of specific ${ }^{125} \mathrm{I}$ insulin binding to intact adipocytes were performed at $16^{\circ} \mathrm{C}$ because insulin internalization is negligible at this low temperature $(1,22,23)$; thus, cell-associated ${ }^{125} \mathrm{I}$-insulin essentially reflects binding to cell surface receptors. After $2 \mathrm{~h}$ the binding reaction was terminated, and specific ${ }^{125}$ I-insulin binding was determined by centrifuging cells (300$\mu$ l aliquots) through oil, as previously described (5). Specific ${ }^{125}$ I-insulin binding was determined in triplicate from each incubation tube, and each experiment was representative of at least three experiments unless otherwise indicated.

\section{Results}

To assess whether insulin-induced receptor loss is necessary for the development of a postreceptor defect in the glucose transport system or whether decreased insulin responsiveness is a direct result of the biologic action of insulin, we preincubated adipocytes for $4 \mathrm{~h}$ at $37^{\circ} \mathrm{C}$ with and without $20 \mathrm{mM}$ Tris in the presence and absence of $100 \mathrm{ng} / \mathrm{ml}$ insulin. All cells were then washed to remove insulin, and glucose transport was allowed to deactivate to basal levels before complete insulin dose-response curves for 2-deoxyglucose uptake were determined. As can be seen in Fig. $1 A$, the dose-response curves were comparable in control and Tris- and insulinpretreated cells. In contrast, in adipocytes preincubated with insulin plus Tris, 2-deoxyglucose uptake was depressed at all insulin concentrations, including maximally effective levels. From the binding data presented in the inset of Fig. $1 \mathrm{~A}$, it is clear that insulin treatment alone did not result in receptor downregulation; only when Tris was added to inhibit recycling did insulin induce a net loss of $65 \%$ of the cell surface receptors. Since $35 \%$ of the original receptor complement was still present, and since only $\sim 10 \%$ of the receptors are needed for maximal effects to stimulate glucose transport (24), the impaired ability of insulin to maximally stimulate glucose transport is due to a postreceptor defect. Thus, insulin alone 

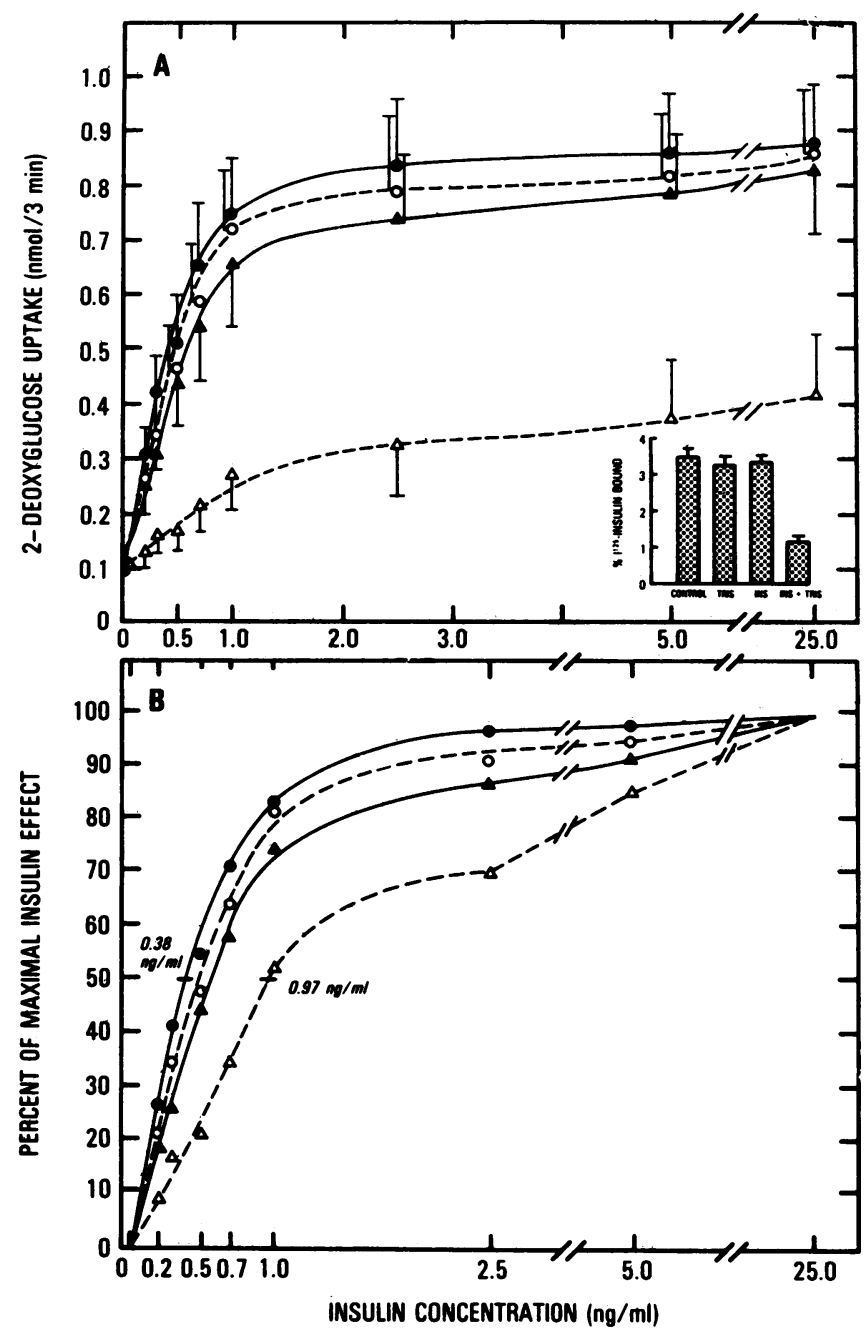

Figure 1. (A) Insulin stimulation of 2-deoxyglucose transport in control and treated adipocytes. Cells were preincubated for $4 \mathrm{~h}$ at $37^{\circ} \mathrm{C}$ in the absence (control, - - ) or presence of $20 \mathrm{mM}$ Tris $\left(--0_{--}\right), 100 \mathrm{ng} / \mathrm{ml}$ insulin $(-\Delta-)$, or Tris plus insulin $(--\Delta--)$ and then washed to remove reagents and insulin (extracellular and receptor bound). After the glucose transport system deactivated to basal levels, cells from each treatment group were re-exposed to the indicated insulin concentrations for $1 \mathrm{~h}$ at $37^{\circ} \mathrm{C}$ before 2-deoxyglucose uptake was determined. The inset shows specific ${ }^{125} \mathrm{I}$-insulin binding to cells from the various groups after a $2 \mathrm{~h}$ incubation at $16^{\circ} \mathrm{C}$. The data for glucose transport and insulin binding represent the mean $\pm S E$ of four experiments, each assayed in triplicate. $(B)$ The mean 2-deoxyglucose uptake data are plotted as a percentage of the maximal insulin effect for the various treatment groups. Calculations were made at each insulin concentration by subtracting the basal from the absolute uptake rate and dividing this value by the maximal increment in uptake (at $25 \mathrm{ng} / \mathrm{ml}$ insulin). Half-maximally effective insulin concentrations are indicated.

did not acutely induce a postreceptor defect in glucose transport. However, when Tris (an inhibitor of receptor recycling) was added during preincubation, both insulin-induced receptor downregulation and a postreceptor defect were subsequently observed.

To better compare the functional form of the dose-response curves; the data were replotted as a percentage of the maximal insulin effect (Fig. $1 \mathrm{~B}$ ). The dose-response curve for insulinplus-Tris-treated cells is shifted to the right 2.6-fold as compared with that for control cells, with half-maximally effective insulin concentrations of 0.97 and $0.38 \mathrm{ng} / \mathrm{ml}$, respectively. This rightward shift is the predicted functional consequence of the decrease in insulin receptors seen in these cells. It is interesting that slight rightward shifts were also observed in the doseresponse curves for cells pretreated with insulin (1.5-fold) and Tris (1.2-fold) in the absence of receptor loss.

Although unlikely, it remained possible that the diminished ability of insulin to maximally stimulate 2-deoxyglucose uptake in insulin-plus-Tris-treated cells was due to defective phosphorylation or rapid dephosphorylation resulting in efflux of this glucose analogue. To test this hypothesis, initial rates of 3-O-methylglucose uptake were measured in control and insulin- and insulin-plus-Tris-pretreated adipocytes. These insulin dose-response curves are shown in Fig. 2. Analagous to results of the experiments with 2-deoxyglucose, the ability of insulin to maximally stimulate 3-O-methylglucose uptake was comparable in control and insulin-treated cells but markedly impaired in cells pretreated with insulin plus Tris. The postreceptor defect is not a manifestation of altered cellular metabolism of 2-deoxyglucose, but rather a direct effect on the rates of insulin-stimulated glucose transport.

The data in Fig. 1 suggested that induction of the postreceptor defect may be linked to receptor downregulation. Therefore, treatment of adipocytes with insulin plus Tris at $16^{\circ} \mathrm{C}$ should not decrease subsequent insulin responsiveness, since at $16^{\circ} \mathrm{C}$ insulin can still fully stimulate glucose transport $(25$, 26), but internalization of insulin-receptor complexes and insulin-induced receptor downregulation are largely inhibited (1, 22, 23). Fig. 3 shows insulin-stimulated 2-deoxyglucose uptake rates and surface insulin binding (inset) in adipocytes pretreated at $16^{\circ} \mathrm{C}$ for $4 \mathrm{~h}$ in the absence and presence of insulin or insulin plus Tris. It is clear that low temperature prevented both insulin-induced receptor loss and induction of the postreceptor defect.

To examine the relationship between insulin-induced receptor downregulation and the postreceptor defect in more

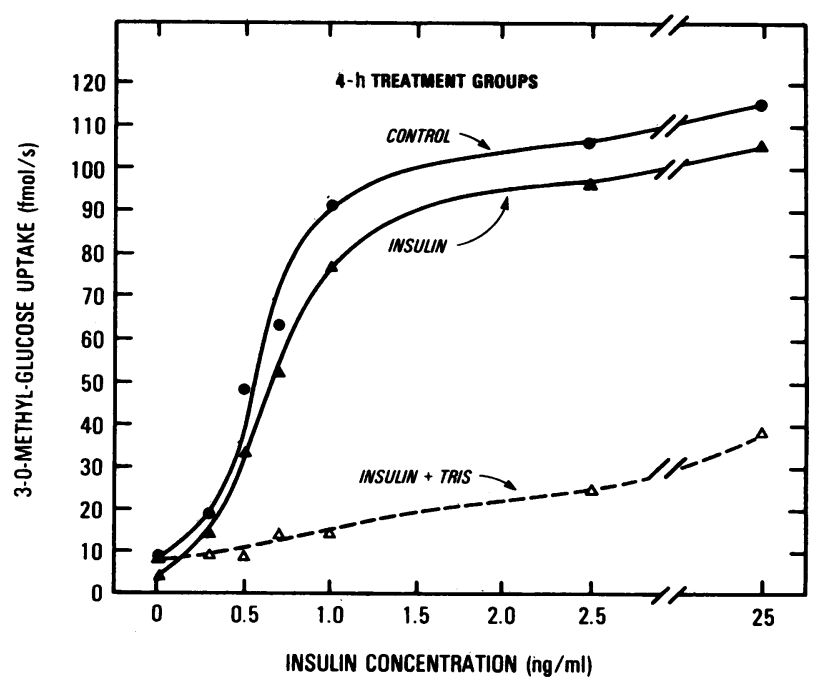

Figure 2. Insulin stimulation of 3-O-methylglucose uptake in control and treated adipocytes. Cells were preincubated and then washed as described for Fig. $1(-\bullet-$, control; $-\Delta-$, insulin; $--\Delta--$, insulin plus Tris), and incubated with insulin concentrations for 30-45 min at $37^{\circ} \mathrm{C}$ before initial rates of substrate uptake were determined. 


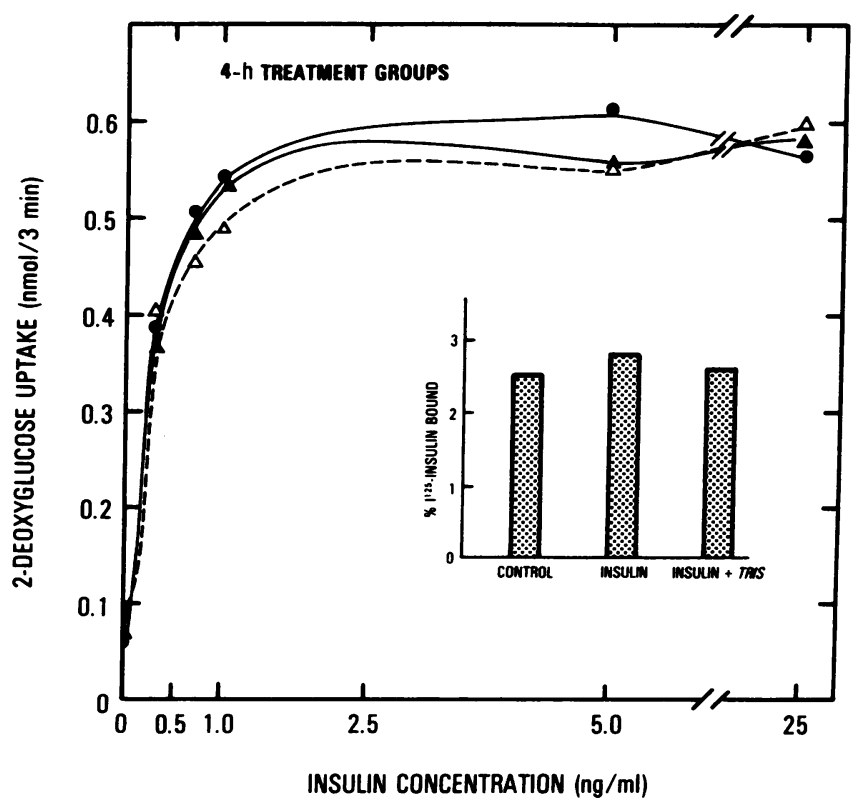

Figure 3. Insulin stimulation of 2-deoxyglucose transport in adipocytes pretreated at $16^{\circ} \mathrm{C}$ for $4 \mathrm{~h}$ in the absence (control, $-\bullet-$ ), or presence of $100 \mathrm{ng} / \mathrm{ml}$ insulin (- - ) or insulin plus $20 \mathrm{mM}$ Tris $(--\Delta--)$. Cells were washed, then incubated with the various insulin concentrations for $1 \mathrm{~h}$ at $37^{\circ} \mathrm{C}$, and 2-deoxyglucose uptake was determined as described for Fig. 1. The inset shows the ability of adipocytes treated in this manner to specifically bind ${ }^{125} \mathrm{I}$-insulin to the cell surface.

detail, we varied the preincubation time (at $37^{\circ} \mathrm{C}$ ) during which adipocytes were exposed to insulin plus Tris. The time course shown in Fig. $4 \mathrm{~A}$ depicts the ability of insulin to progressively decrease maximally stimulated rates of glucose transport and produce a loss of surface receptors. It is evident that the postreceptor defect is not observable until $2 \mathrm{~h}$ of preincubation, whereas loss of insulin receptors occurs almost immediately. However, once the postreceptor defect appears, it increases in severity in association with progressive receptor loss until both responses reach their nadir after 4-6 $h$ of preincubation. This is further illustrated in Fig. $4 \mathrm{~B}$, which shows the correlation between the percent receptor downregulation and postreceptor defect after various preincubation times. To further assess this relationship using a different approach, we altered the number of cell surface receptors by varying the insulin concentration while keeping the preincubation time constant. As Fig. 5 shows, both the postreceptor defect (i.e., decreased maximally stimulated glucose transport) and receptor loss progressed in severity as the insulin concentration was increased during a 4-h preincubation, until both responses approached maximal at a pretreatment insulin level of $\sim 20 \mathrm{ng} / \mathrm{ml}$. This indicates that a certain percentage of receptors must be lost before decreased maximal transport rates are noted (Fig. 4), but with further receptor loss the magnitude of the postreceptor defect is correlated to the degree of insulin receptor downregulation (Figs. 4 and 5).

To examine the specificity of insulin to induce this postreceptor defect, we studied the effects of the insulin mimicker spermine, in the presence of Tris, on insulin receptors and glucose transport. Under these conditions, spermine stimulates glucose transport via a mechanism that apparently does not involve the insulin receptor, and, therefore, receptor downreg-
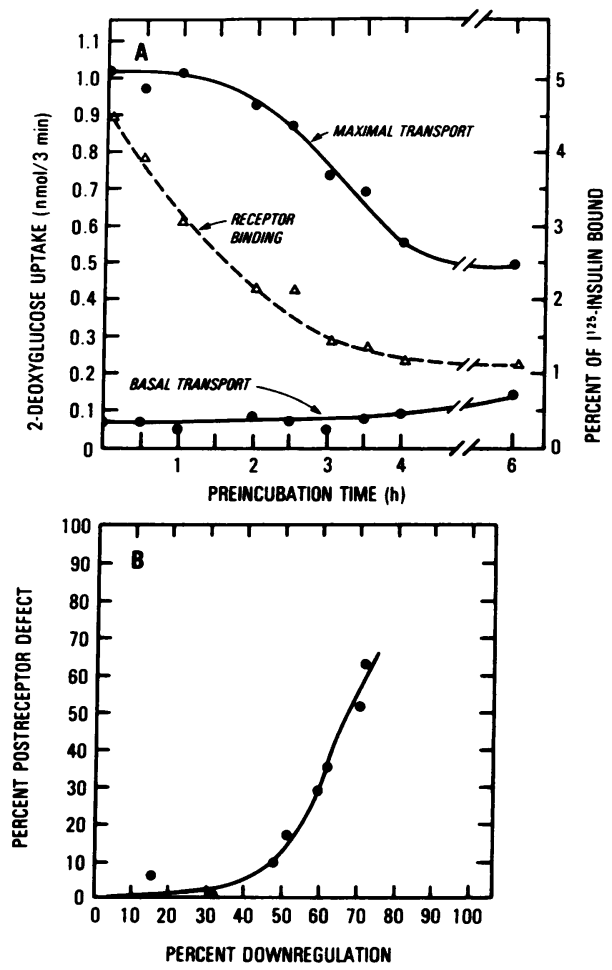

Figure 4. $(A)$ The relationship between basal and maximally stimulated rates of 2-deoxyglucose uptake (- - ) and insulin binding $(--\Delta--)$ as a function of insulin preincubation time. Cells were treated with $100 \mathrm{ng} / \mathrm{ml}$ insulin and $20 \mathrm{mM}$ Tris at $37^{\circ} \mathrm{C}$ for $0-6 \mathrm{~h}$ and then washed in insulin-free and Tris-free buffer. Basal and maximally stimulated $(25 \mathrm{ng} / \mathrm{ml}$ insulin) rates of 2-deoxyglucose uptake, and specific binding of ${ }^{125} \mathrm{I}$-insulin, were determined as described for Fig. 1. (B) The correlation between the percent postreceptor defect and receptor downregulation, as each response progresses during preincubation. The percent postreceptor defect is defined as the decrease in insulin-mediated glucose transport (maximally stimulated minus basal glucose transport rate) expressed as a percentage of the corresponding value at time zero. The percent downregulation is the percent specific surface ${ }^{125}$ I-insulin binding relative to time zero.

ulation does not occur (27). In the first part of the experiment, the preincubation phase (Fig. $6 \mathrm{~A}$ ), cells were incubated in the presence of Tris in the absence (control) and presence of insulin $(0.7$ or $100 \mathrm{ng} / \mathrm{ml})$ or $1 \mathrm{mM}$ spermine. Several aspects of this protocol should be noted. First, the medium was replaced after $3 \mathrm{~h}$ with an equal volume of medium containing freshly added reagents, since preliminary experiments indicated that the full stimulatory effect of spermine is maintained for only 3 to $4 \mathrm{~h}$. Second, since the maximal stimulatory effects of spermine were slightly less than the maximal effects of insulin, we also used an insulin concentration $(0.7 \mathrm{ng} / \mathrm{ml})$ that stimulated glucose transport to the same degree as spermine. In the second half of the experiment, cells were washed after 4 or $6 \mathrm{~h}$ of preincubation, and glucose transport was allowed to deactivate. Basal and maximally insulin-stimulated rates of glucose transport were then measured in all treatment groups; the data are shown in Fig. $6 \mathrm{~B}$. As can be seen, adipocytes preincubated with Tris plus spermine for either 4 or $6 \mathrm{~h}$ exhibited no decrease in maximal glucose transport rates upon restimulation with insulin (i.e., no postreceptor defect); furthermore, there was no loss of surface insulin receptors (data not shown). In contrast, in cells pretreated with either high 

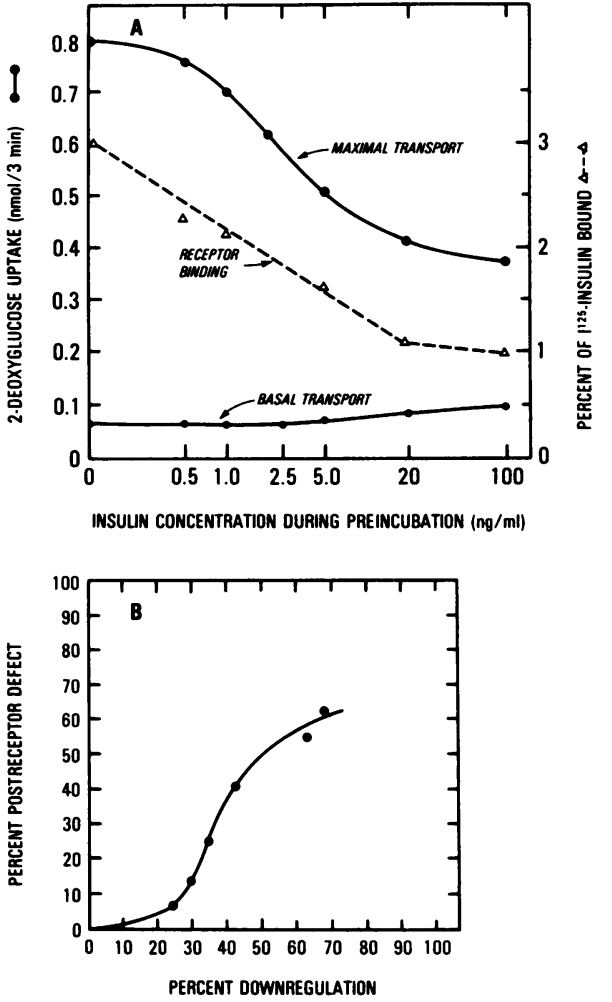

Figure 5. $(A)$ The dose-response of the ability of insulin to affect basal and maximally stimulated rates of 2-deoxyglucose uptake $(-\bullet-)$ and insulin binding (-- --$)$. Cells were preincubated with the indicated insulin concentrations and $20 \mathrm{mM}$ Tris for $4 \mathrm{~h}$ at $37^{\circ} \mathrm{C}$, and then washed in insulin-free and Tris-free buffer. Basal and maximally stimulated $(25 \mathrm{ng} / \mathrm{ml}$ insulin) rates of 2-deoxyglucose uptake, and specific binding of ${ }^{125} \mathrm{I}$-insulin to the cell surface, were determined as described for Fig. 1. (B) The correlation between the percent postreceptor defect and percent receptor downregulation at the various preincubation insulin concentrations. The values were calculated as in Fig. $4 \mathrm{~B}$.
$(100 \mathrm{ng} / \mathrm{ml})$ or low $(0.7 \mathrm{ng} / \mathrm{ml})$ dose insulin, maximal glucose transport was decreased by 55 and $17 \%$, respectively, at $4 \mathrm{~h}$, and by 58 and $31 \%$, respectively, at $6 \mathrm{~h}$. Concomitantly, receptor loss was 63 and $21 \%$ by $4 h$ and 67 and $36 \%$ by $6 h$ in the presence of 100 or $0.7 \mathrm{ng} / \mathrm{ml}$ insulin, respectively. Thus, stimulation of glucose transport by spermine, even in the presence of Tris, does not induce a postreceptor defect, which indicates that the generation of the postreceptor defect is specific for insulin under conditions where receptor loss occurs.

We also tested whether Tris itself could have any direct effects on the glucose transport system. The results indicate that any effect of $20 \mathrm{mM}$ Tris is reversible during the washing procedures that remove Tris from the system. Thus, preincubation with Tris, either under basal conditions (Fig. 1) or while the glucose transport system is maintained in an activated state by spermine (Fig. 6), does not impair the subsequent ability of the insulin to maximally stimulate glucose transport. Therefore, the postreceptor defect seen after preincubaion with insulin plus Tris cannot be attributed directly to any lasting effect of Tris. However, to assess any acute effects of Tris, we performed the experiment shown in Fig. 7. Glucose transport rates were assessed as a function of time during $4 \mathrm{~h}$ of incubation in Tris and then for $2 \mathrm{~h}$ more after the cells were washed in a Tris-free buffer. As can be seen, Tris acutely produced a relatively small decrease $(22 \%)$ in maximally stimulated rates of glucose transport, but this effect was rapidly reversible (20-30 min) after Tris removal. No effect of $20 \mathrm{mM}$ Tris on the basal transport rate was observed.

To better understand the mechanism of the postreceptor defect, the Michaelis constant $\left(K_{\mathrm{m}}\right)$ and maximum velocity $\left(V_{\max }\right)$ values of glucose transport were assessed in cells pretreated with insulin plus Tris or Tris alone. Initial rates of 3$O$-methylglucose uptake were measured as a function of substrate concentration under basal and maximally insulin-stimulated conditions; an Eadie-Hofstee plot of these data is presented in Fig. 8. In both treatment groups, $K_{\mathrm{m}}$ and $V_{\max }$ values were comparable under basal conditions $\left(K_{\mathrm{m}}, 8.7\right.$ vs. 8.6
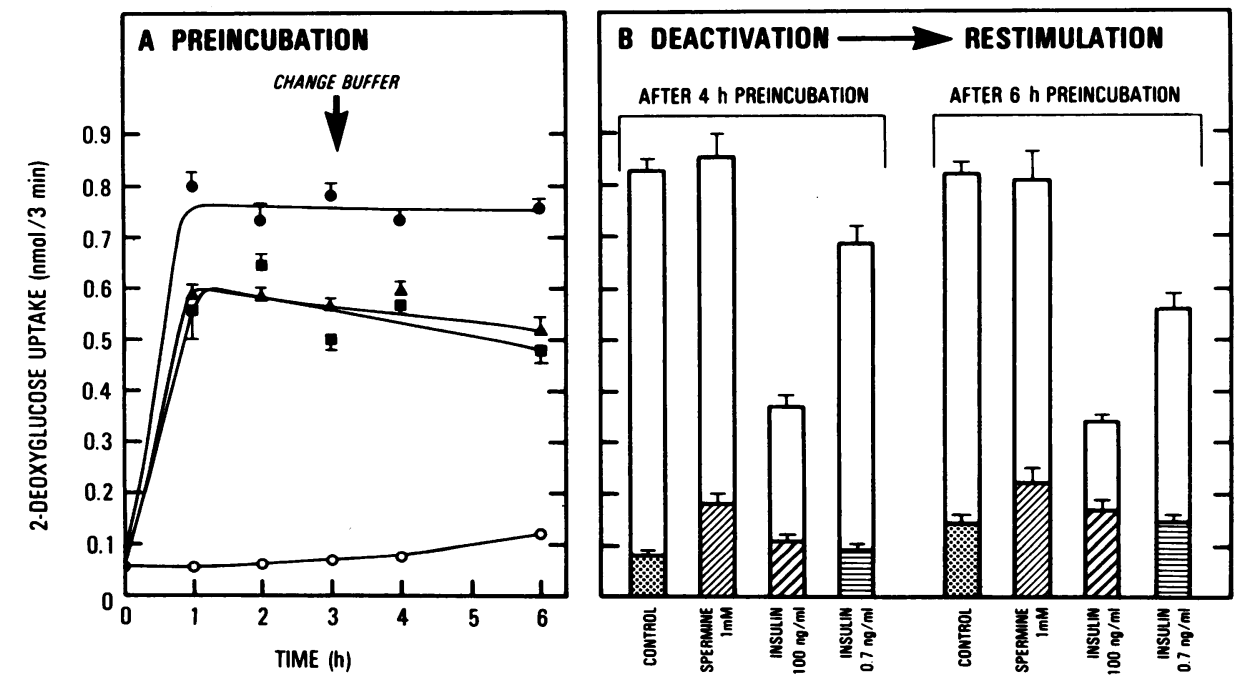

Figure 6. Comparison of the effects of spermine and insulin preincubation on basal and maximally insulin-stimulated 2-deoxyglucose uptake rates in adipocytes. $A$ shows 2-deoxyglucose uptake rates during preincubation. All groups were preincubated at $37^{\circ} \mathrm{C}$ with $20 \mathrm{mM}$ Tris in the absence (control, $-\mathrm{O}_{-}$) or presence of $1 \mathrm{mM}$ spermine $(--)$, or with submaximal insulin $(0.7 \mathrm{ng} / \mathrm{ml}$, - 4 -) or maximal insulin $(100 \mathrm{ng} / \mathrm{ml}$, - - ) insulin. After $3 \mathrm{~h}$, the buffer was replaced with an equal volume of buffer containing freshly added reagant. After 4 and $6 \mathrm{~h}$ or preincubation, cells were washed in reagent-free buffer and the glucose transport system was allowed to deactivate. $B$ shows basal (hatched bars) and maximally insulin-stimulated (25 $\mathrm{ng} / \mathrm{ml}$; open bars) rates of 2-deoxyglucose uptake in cells from the various preincubation treatment groups. The data represent the mean \pm SE of three experiments each assayed in triplicate. 


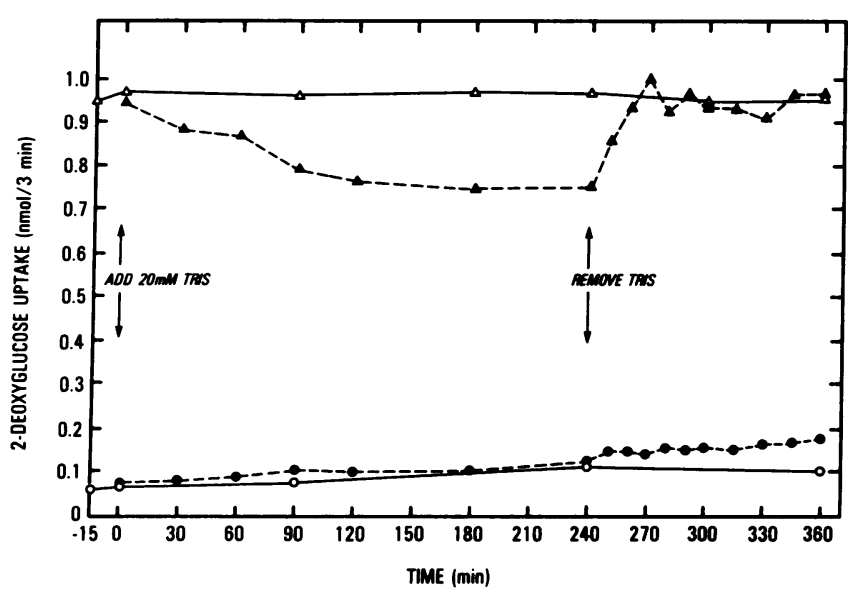

Figure 7. The effect of $20 \mathrm{mM}$ Tris on basal and maximally stimulated rates of 2-deoxyglucose uptake in adipocytes. Cells were pretreated for $30 \mathrm{~min}$ at $37^{\circ} \mathrm{C}$ with and without $50 \mathrm{ng} / \mathrm{ml}$ insulin, and then basal and maximally stimulated rates of 2-deoxyglucose uptake were assessed as a function of time in the absence and presence of added Tris. After $4 \mathrm{~h}$ of incubation at $37^{\circ} \mathrm{C}$, all cells were quickly washed twice in an equal volume of Tris-free buffer that either did (maximally stimulated) or did not (basal) contain $50 \mathrm{ng} / \mathrm{ml}$ insulin. $-\Delta-$, maximally stimulated control; -- $\Delta--$, maximally stimulated Tris; -०-, basal control; --•--, basal Tris.

$\mathrm{mM}$; and $V_{\max }, 13.2$ and $13.6 \mathrm{pmol} / \mathrm{s}$ per $2 \times 10^{5}$ cells in Tris- and Tris-plus-insulin-pretreated cells, respectively). Furthermore, in both treatment groups the effect of insulin to stimulate glucose uptake was due to an increase in the $V_{\max }$ of transport with no change in $K_{\mathrm{m}}$. However, the ability of insulin in Tris-plus-insulin-treated cells, which exhibit a

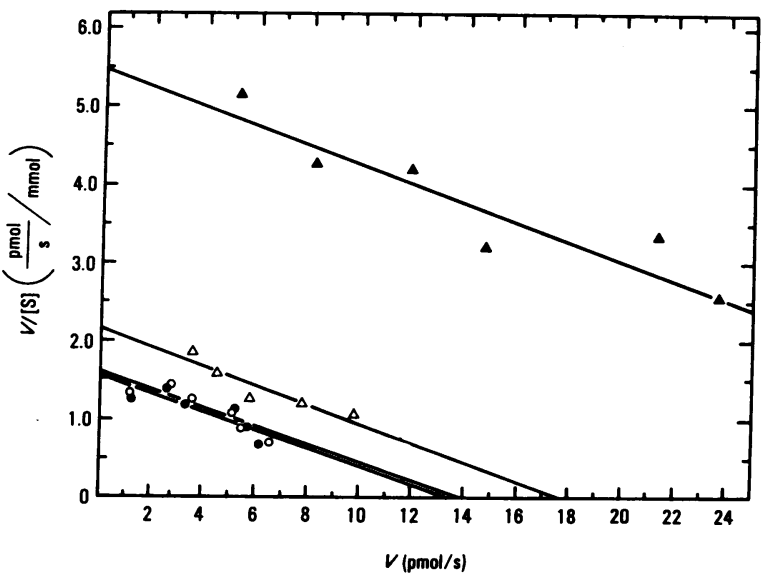

Figure 8. Eadie-Hofstee plot of 3-O-methylglucose uptake rates assayed as a function of substrate concentration in pretreated adipocytes. Cells were preincubated with $20 \mathrm{mM}$ Tris in the presence and absence of $100 \mathrm{ng} / \mathrm{ml}$ insulin for $4 \mathrm{~h}$ at $37^{\circ} \mathrm{C}$, and then washed in insulin-free and Tris-free buffer. Cells were then incubated in the absence (basal) and presence of a maximally effective insulin concentration $(50 \mathrm{ng} / \mathrm{ml})$ for $30-45 \mathrm{~min}$ at $37^{\circ} \mathrm{C}$, and initial rates of $3-O$ methylglucose uptake were measured in buffer that contained various concentrations of the substrate $(0.1$ to $9.1 \mathrm{mM})$ including $0.2 \mu \mathrm{Ci}$ of $3-O$-methyl[ $\left.{ }^{14} \mathrm{C}\right]$ glucose. Each data point reflects substrate uptake in $\sim 66,000$ adipocytes and is the mean of two experiments each assayed in duplicate. $\Delta$, Tris alone, maximally stimulated; $\Delta$, Tris plus insulin, maximally stimulated; $\circ$, Tris plus insulin, basal; $\bullet$, Tris alone, basal. postreceptor defect, to increase $V_{\max }$ was markedly impaired $\left(17.3 \mathrm{pmol} / \mathrm{s}\right.$ per $2 \times 10^{5}$ cells) as compared with that in cells preincubated in the absence of insulin $(46.6 \mathrm{pmol} / \mathrm{s}$ per 2 $\times 10^{5}$ cells).

It is apparent in Fig. 6 that the postreceptor defect (in cells treated for 4 or $6 \mathrm{~h}$ with insulin plus Tris) is seen only after the glucose transport system is allowed to deactivate, since the decrease in insulin responsiveness is not noted when glucose transport is maintained in a fully activated state. To assess the relationship between the extent of deactivation and the expression of the postreceptor defect, we preincubated adipocytes with insulin plus Tris, and then examined the ability of insulin to maximally restimulate glucose transport after various times of deactivation. As can be seen in Fig. 9, at $15 \mathrm{~min}$ after insulin removal, glucose transport in those adipocytes had deactivated $\sim 50 \%$ as compared with that in cells continuously treated with insulin. Maximal insulin, added at this point, did not further re-activate the glucose transport system; however, further deactivation was prevented as glucose transport rates were maintained at this lower level over the next 30-75 min. Beyond 15 min of deactivation, added insulin could restimulate glucose transport only to a fixed degree, equal to the magnitude of the postreceptor defect. If insulin was added before $15 \mathrm{~min}$ of deactivation, the level of deactivation determined the extent to which insulin could maximally restimulate glucose transport. That is, as deactivation progressed over these earlier time points, added insulin maintained glucose transport at progressively lower levels over the next 105-120 min; however, these transport rates were never greater than the level of deactivation at the time insulin was added. Thus, the expression of the postreceptor defect (upon restimulation by insulin) is related to the extent of glucose transport deactivation.

\section{Discussion}

In the current study we have examined whether induction of a postreceptor defect in insulin-stimulated glucose transport is

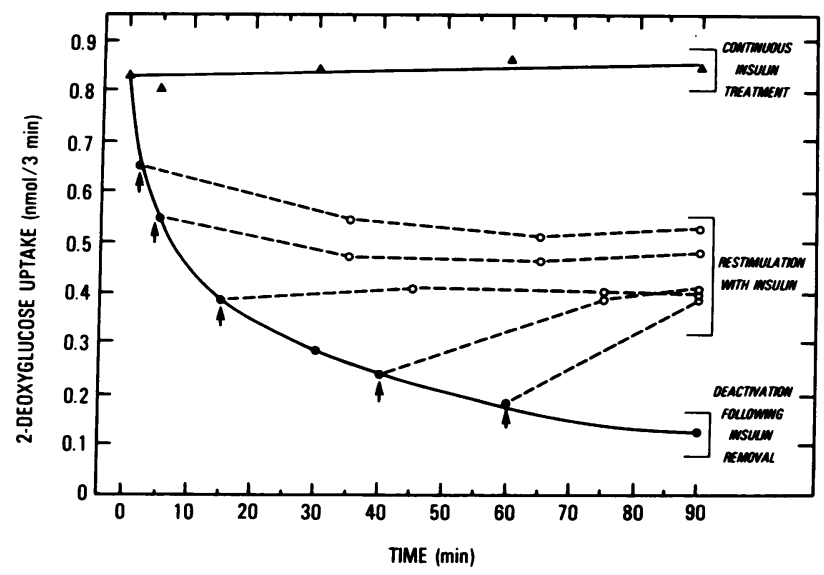

Figure 9. Deactivation and restimulation of the glucose transport system in pretreated adipocytes. Cells were preincubated with $100 \mathrm{ng} /$ $\mathrm{ml}$ insulin and $20 \mathrm{mM}$ Tris for $4 \mathrm{~h}$ at $37^{\circ} \mathrm{C}$, and then washed four times in equal volumes of insulin-free and Tris-free buffer at $12^{\circ} \mathrm{C}$. The cells were then immediately warmed to $37^{\circ} \mathrm{C}$ (time, $0 \mathrm{~min}$ ) and the glucose transport system was either allowed to deactivate or was maintained in a fully activated state by the re-addition of insulin (25 $\mathrm{ng} / \mathrm{ml}$ ) at time $0 \mathrm{~min}$. In deactivating cells at the times indicated by arrows, insulin $(25 \mathrm{ng} / \mathrm{ml})$ was re-added and glucose uptake was assessed in each group of cells over the next 30-90 min. 
linked to insulin receptor downregulation. When adipocytes were pretreated with insulin and Tris at $16^{\circ} \mathrm{C}$, a temperature that prevents internalization of ligand-receptor complexes and downregulation $(1,22,23)$ but still allows insulin to fully stimulate glucose transport $(25,26)$, no postreceptor defect in the subsequent ability of insulin to promote glucose transport was observed. Since the rate of activation of glucose transport is decreased at $16^{\circ} \mathrm{C}(25,26)$, it is possible that low temperature may have simply delayed the formation of a postreceptor defect. However, this is unlikely since full transport activation is seen at $16^{\circ} \mathrm{C}$ by $20-30 \mathrm{~min}(26)$, and only $2-3 \mathrm{~h}$ of incubation were required to induce a postreceptor defect (Fig. 4). Thus, the 4-h incubation with insulin plus Tris should have been sufficient to observe a postreceptor defect if one had occurred. Internalization of ligand-receptor complexes per se is also insufficient, since incubation of cells at $37^{\circ} \mathrm{C}$ with insulin alone in the absence of Tris results in receptor uptake but does not impair postreceptor insulin action. Under the latter conditions, there is no net loss of surface insulin receptors due to efficient recycling of internalized receptors (3-5). Only when cells are pretreated with insulin and Tris at $37^{\circ} \mathrm{C}$ to produce a net loss of cell surface receptors does insulin induce the postreceptor defect. Furthermore, induction of the postreceptor defect is insulin specific, since activation of glucose transport with the insulin mimicker spermine, under identical experimental conditions, does not decrease insulin responsiveness. When we examined the relationship between insulininduced receptor downregulation and the postreceptor effect in more detail, we found that receptor loss occurs first without loss of insulin responsiveness, but once the postreceptor defect appears its severity is then correlated to the degree of further receptor downregulation. Taken together, the data indicate that under these experimental conditions an insulin-induced loss of surface receptors may be necessary for the formation of a postreceptor defect in glucose transport and that, in the absence of receptor loss, insulin alone does not acutely lead to a decrease in glucose transport responsiveness.

In these experiments, insulin-induced receptor loss never exceeded the level of spare receptors for insulin action (24, 28 ), and, therefore, a decrease in the glucose transport rate at maximally effective insulin concentrations is consistent with a postreceptor defect. Such a defect would more properly be termed a postbinding defect if insulin induced a structural or functional change in the receptor itself that adversely affected the promulgation of the insulin signal, e.g., if it reduced insulin receptor kinase activity (29). However, the site of this defect appears to lie distal to the insulin receptor since previous data have shown that spermine, which may activate glucose transport independent of the insulin receptor $(27,30)$, was also ineffective in eliciting a maximal response in these cells. Thus, even though the postreceptor defect in the glucose transport system lies distal to the insulin receptor, it is induced via a mechanism linked in some way to the receptor itself. It remains possible that a product associated with internalization of insulin-receptor complexes and that accumulates rapidly in the presence of Tris mediates the induction of the postreceptor defect. Similarly, some other biologic product of insulin action that accumulates in the presence of Tris may be responsible, but this factor would not appear at $16^{\circ} \mathrm{C}$ or be produced by spermine. In these latter formulations, the continued presence of insulin alone at $37^{\circ} \mathrm{C}$ may eventually induce a postreceptor defect (once products of internalized ligand-receptor complexes or insulin action can accumulate), even though a net decrease in the number of surface receptors does not occur.

To further define the locus and mechanism of the postreceptor defect, we determined that the diminished rate of maximally stimulated glucose transport was due to a decrease in the $V_{\max }$ with no change in the $K_{\mathrm{m}}$ of glucose uptake. In the standard carrier model for facilitated diffusion, a $V_{\max }$ defect would result from decreased numbers of functioning plasma membrane transporters, decreased mobility of glucose through existing carriers, or both (31). We favor the former possibility since it is consistent with other studies that show that insulin resistance in the rat, induced by a high-fat diet (32), fasting (33), streptozotocin treatment (34), or obesity (35), is associated with a decrease in the actual number of glucose transporters in adipocytes.

The continued presence of insulin during preincubation prevents the expression of the postreceptor abnormality, as we showed previously (2). We have now expanded this observation by showing that the degree to which the postreceptor defect is expressed, after insulin removal and upon restimulation with the hormone, is related to the extent of glucose transport deactivation. These findings allow certain speculations about the mechanism of the postreceptor defect in the context of the "translocation model," in which a maximal insulin concentration activates glucose transport by recruiting about half of the intracellular transporters to the plasma membrane in rat adipocytes $(36,37)$. Thus, one possible mechanism to explain our data is that, as the glucose transport system deactivates and glucose carriers retranslocate back to the cell interior, there is a rapid alteration or sequestration of these transporters such that insulin can no longer recruit full numbers back to the cell surface. Since early during deactivation added insulin does not further re-activate the glucose transport system, insulin may also be unable to recruit to the plasma membrane any of those glucose transporters that had remained in the cell interior initially. This indicates that insulin can recruit $50 \%$ of the intracellular transporters to the cell surface under full stimulatory conditions, and that the cohort of intracellular transporters that stay behind does not participate in further cycles of stimulation. These inactive or inaccessible transporters may be structurally different or reside in a different subcellular compartment, perhaps serving to replenish the actively translocating transporters when they are eventually degraded. Of course, these hypotheses are highly speculative but could be tested by direct measurement of the number and cellular distribution of glucose transporters $(36,37)$. In any event, the induced abnormality in glucose transport does not affect transporters while they reside on the cell surface in the presence of insulin, since deactivation of glucose transport (with presumed movement back to the cell interior) is necessary for expression of the postreceptor defect.

Since insulin was used to induce loss of surface receptors in the presence of $20 \mathrm{mM}$ Tris, an inhibitor of recycling, it was possible that the postreceptor defect may have resulted from some effect of Tris on the glucose transport system. Simpson et al. (38) reported that when rat adipocytes are stimulated with insulin there are reduced numbers of plasma membrane glucose transporters in the presence of $40 \mathrm{mM}$ Tris, along with decreased maximally stimulated rates of glucose transport. Although basal rates of glucose transport were not affected in this study, Tris did acutely induce a translocation of inactive D-glucose-inhibitable cytochalasin B 
binding sites from an intracellular locus to the plasma membrane. In the current study, any effect of Tris on the glucose transport system during preincubation is reversible during the washing procedures that remove Tris from the system before the transport assays. For example, cells pretreated with Tris alone in the basal state, or while the glucose transport system is maintained in an activated state by spermine, have maximal insulin-stimulated glucose transport rates comparable to those of control cells after the removal of Tris and spermine and deactivation of glucose transport. Indeed, when directly studied, $20 \mathrm{mM}$ Tris did acutely decrease maximally stimulated rates of glucose transport slightly, and this effect was rapidly reversible with Tris removal. Thus, since the acute effect of Tris is reversible under these experimental conditions, the postreceptor defect seen after preincubation with insulin plus Tris cannot be attributed to any lasting effect of Tris per se. We conclude that Tris does not have a primary role in the induction of the postreceptor defect.

Insulin has previously been shown to induce combined receptor and postreceptor defects in vitro for other insulin actions (6-12). The important point is that, uniformly in these studies, decreased insulin responsiveness was associated with insulin receptor downregulation. Insulin has also induced a postreceptor defect in insulin-like growth factor I and II stimulation of tyrosine aminotransferase activity in rat hepatoma cells, also accompanied by loss of cell-surface insulin receptors (39). Although the relationship between insulin receptor downregulation and the induction of postreceptor defects remains unclear in these individual studies, the results of the current study suggest that these processes may be mechanistically linked for these other insulin actions.

Little other information exists as to whether insulin can regulate its own ability to stimulate glucose transport. This potential regulatory role is of interest since combined receptor and postreceptor defects have been identified in the insulinresistant states of obesity (17) and type II diabetes mellitus (13) by the use of measurements of in vivo glucose disposal, and these are both states characterized by hyperinsulinemia. Furthermore, the postreceptor defect in adipocytes isolated from both obese (16) and type II diabetic (14) subjects is associated with decreased activity of the glucose transport system. Again, it is unclear whether the formation of a postreceptor defect is related to receptor loss in these states. It is interesting that other clinical states have been identified in which postreceptor defects are present without receptor loss (40-42), raising the possibility that postreceptor defects could be induced at multiple sites of which only one is linked to receptor downregulation. In the current study, insulin has been shown to induce a postreceptor defect involving the glucose transport system that is linked in some way to the loss of cell surface receptors. It is possible, based on this in vitro study using a classical insulin target tissue, that the postreceptor defect that mediates insulin resistance in obesity and noninsulin dependent diabetes mellitus evolves through a mechanism linked to the insulin receptor downregulation present in target tissues.

\section{Acknowledgments}

We thank Cleon Tate and Elizabeth Martinez for their secretarial assistance.

This work was supported by research grants AM 33647 and AM
34402 (to Dr. Marshall) and AM 33651 and AM 33650 (to Dr. Olefsky) from the National Institutes of Health. Dr. Garvey is a recipient of a Pfizer Postdoctoral Fellowship Award. Dr. Marshall is a recipient of Research Career Development Award AM 01357 from the National Institutes of Health.

\section{References}

1. Marshall, S., and J. M. Olefsky. 1981. Characterization of insulin-induced receptor loss and evidence for internalization of the insulin receptor. Diabetes. 30:746-753.

2. Marshall, S., and J. M. Olefsky. 1980. Effects of insulin incubation on insulin binding, glucose transport, and insulin degradation by isolated rat adipocytes: evidence for hormone-induced desensitization of the receptor and postreceptor level. J. Clin. Invest. 66:763-772.

3. Marshall, S., A. Green, and J. M. Olefsky. 1981. Evidence for recycling of insulin receptors in isolated rat adipocytes. J. Biol. Chem. 256:11464-11470.

4. Marshall, S., and J. M. Olefsky. 1981. Tris(hydroxymethyl)aminomethane permits the expression of insulin-induced receptor loss in isolated rat adipocytes. Biochem. Biophys. Res. Commun. 102:646-653.

5. Marshall, S., W. T. Garvey, and M. Geller. 1984. Primary culture of isolated adipocytes: a new model to study insulin receptor regulation and insulin action. J. Biol. Chem. 259:6376-6384.

6. Chang, T. H., and S. E. Polakis. 1978. Differentiation of 3T3L1 fibroblasts to adipocytes: effect of insulin and indomethacin on the levels of insulin receptors. J. Biol. Chem. 253:4693-4696.

7. Heaton, J. H., and T. D. Gelehrter. 1981. Desensitization of hepatoma cells to insulin action: evidence for a post-receptor mechanism. J. Biol. Chem. 256:12257-12262.

8. Grimaldi, P., R. Negrel, J. P. Vincent, and G. Ailhaud. 1979. Differentiation of ob 17 preadipocytes to adipocytes. J. Biol. Chem. 254:6849-6852.

9. Heaton, J. H., and T. D. Gelehrter. 1980. Regulation of insulin responsiveness in rat hepatoma cells. Biochem. Biophys. Res. Commun. 92:795-802.

10. Krett, N. L., J. H. Heaton, and T. D. Gelehrter. 1983. Insulin resistance in $\mathrm{H}-35$ rat hepatoma cells is mediated by post-receptor mechanisms. Mol. Cell. Endocrinol. 32:91-100.

11. Crettaz, M., and C. R. Kahn. 1984. Insulin receptor regulation and desensitization in rat hepatoma cells: concomitant changes in receptor number and in binding affinity. Diabetes. 33:477-485.

12. Stevens, J., R. L. Atkinson, and S. L. Pohl. 1980. Insulininduced insulin resistance of lipolysis in human adipocytes in organ culture. J. Clin. Endocrinol. \& Metab. 51:921-924.

13. Kolterman, O. G., R. S. Gray, J. Griffin, P. Burstein, J. Insel, J. A. Scarlett, and J. M. Olefsky. 1981. Receptor and postreceptor defects contribute to the insulin resistance in non-insulin dependent diabetes mellitus. J. Clin. Invest. 68:957-969.

14. Ciaraldi, T. P., O. G. Kolterman, J. A. Scarlett, M. Kao, and J. M. Olefsky. 1982. Role of the glucose transport system in the postreceptor defect of non-insulin dependent diabetes mellitus. Diabetes. 31:1016-1022.

15. Cushman, S. W., D. Nada, and L. B. Salans. 1981. Adipose cell size-function relationships: insulin binding and degradation. Am. J. Physiol. 240:E166-E174.

16. Ciaraldi, T. P., O. G. Kolterman, and J. M. Olefsky. 1981. Mechanisms of the postreceptor defect in insulin action in human obesity: decrease in intrinsic activity of the glucose transport system. J. Clin. Invest. 68:875-880.

17. Kolterman, O. G., J. Insel, M. Saekow, and J. M. Olefsky. 1980. Mechanisms of insulin resistance in human obesity: evidence for receptor and postreceptor defects. J. Clin. Invest. 65:1273-1284.

18. Rodbell, M. 1964. Metabolism of isolated fat cells. I. Effects of hormones on glucose metabolism and lipolysis. J. Biol. Chem. 239: 375-380. 
19. Hirsch, J., and E. Gallian. 1968. Methods for the determination of adipose cell size in man and animals. J. Lipid Res. 9:110-119.

20. Whitesell, R. R., and J. Gliemann. 1979. Kinetic parameters of transport of 3-O-methylglucose and glucose in adipocytes. J. Biol. Chem. 254:5276-5283.

21. Foley, J. E., R. Foley, and J. Gliemann. 1980. Rate-limiting steps of 2-deoxyglucose uptake in rat adipocytes. Biochim. Biophys. Acta. 599:689-698.

22. Olefsky, J. M., and M. Kao. 1982. Surface binding and rates of internalization of ${ }^{125}$ I-insulin in adipocytes and IM-9 lymphocytes. J. Biol. Chem. 257:8667-8673.

23. Heidenreich, K. A., P. Berhaniu, D. Brandenburg, and J. M. Olefsky. 1983. Degradation of insulin receptors in rat adipocytes. Diabetes. 32:1001-1009.

24. Kono, T., and F. W. Barham. 1971. The relationship between the insulin binding capacity of fat cells and the cellular response to insulin. J. Biol. Chem. 246:6210-6216.

25. Ezaki, O., and T. Kono. 1982. Effects of temperature on basal and insulin-stimulated glucose transport activated in fat cells: further support for the translocation hypothesis of insulin action. J. Biol Chem. 257:14306-14310.

26. Simpson, I. A., M. J. Zarnowski, and S. W. Cushman. 1983. Mechanism of insulin's stimulatory action on glucose transport: effects of low temperature. Fed. Proc. 42:1970a. (Abstr.)

27. Lockwood, D. H., and L. E. East. 1974. Studies of the insulinlike actions of polyamines on lipid and glucose metabolism in adipose tissue cells. J. Biol. Chem. 249:7717-7722.

28. Kahn, C. R. 1978. Insulin resistance, insulin insensitivity, and insulin unresponsiveness: a necessary distinction. Metab. Clin. Exp 27:1893-1902.

29. Kasuga, M., F. A. Karlsson, and C. R. Kahn. 1982. Insulin stimulates the phosphorylation of the 95,000 dalton subunit of its own receptor. Science (Wash. DC). 215:185-187.

30. Haring, J. U., M. Kasuga, and C. R. Kahn. 1982. Insulin receptor phosphorylation in intact adipocytes and in a cell-free system. Biochem. Biophys. Res. Commun. 108:1538-1545.

31. Olefsky, J. M. 1978. Mechanisms of the ability of insulin to activate the glucose transport system in rat adipocytes. Biochem. $J$ 172:137-145
32. Hissin, P. J., E. Karnieli, I. A. Simpson, L. B. Salans, and S. W. Cushman. 1982. A possible mechanism of insulin resistance in the rat adipose cell with high fat/low carbohydrate feeding. Diabetes. 31:589-592.

33. Kahn, B. B., and S. W. Cushman. 1984. Effects of fasting and refeeding on the distribution of glucose transporters in isolated rat adipocytes. Diabetes. 33(Suppl. 1):71A. (Abstr.)

34. Karnieli, E., P. J. Hissin, I. A. Simpson, L. B. Salans, and S. W. Cushman. 1981. A possible mechanism of insulin resistance in the rat adipose cell in streptozotocin-induced diabetes mellitus. J. Clin. Invest. 68:811-814.

35. Hissin, P. J., J. E. Foley, L. J. Wardzala, E. Karnieli, I. A. Simpson, L. B. Salans, and S. W. Cushman. 1982. Mechanisms of insulin-resistant glucose transport activity in the enlarged adipose cell of the aged obese rat. J. Clin. Invest. 70:780-790.

36. Cushman, S. W., and L. J. Wardzala. 1980. Potential mechanisms of insulin action on glucose transport in the isolated rat adipose cell: apparent translocation of intracellular transport systems to the plasma membrane. J. Biol. Chem. 255:4758-4762.

37. Suzuki, K., and T. Kono. 1980. Evidence that insulin causes translocation of glucose transport activity to the plasma membrane from an intracellular storage site. Proc. Natl. Acad. Sci. USA. 77:25422545.

38. Simpson, I. A., M. L. Martin, and S. W. Cushman. 1982. Effects of Tris on insulin's stimulation of glucose transport in rat adipose cells. Diabetes. 31(Suppl. 2):29A. (Abstr.)

39. Heaton, J. H., N. L. Krett, J. M. Alvarez, T. D. Gelehrter, J. A. Romanus, and M. M. Rechler. 1984. Insulin regulation of insulin-like growth factor action in rat hepatoma cells. J. Biol. Chem. 259:2396-2402.

40. Fink, R. I., O. G. Kolterman, J. Griffin, and J. M. Olefsky. 1983. Mechanisms of insulin resistance in aging. J. Clin. Invest. 71 : 1588-1596.

41. Rizza, R. A., L. J. Mandarino, and J. E. Gerich. 1982. Effects of growth hormone on insulin action in man. Diabetes. 31:663-669.

42. Puavilai, G., E. C. Grobny, L. A. Doment, and G. Baumann. 1982. Insulin receptors and insulin resistance in human pregnancy: evidence for a postreceptor defect in insulin action. J. Clin. Endocrinol. \& Metab. 54:247-253. 